\title{
ТАКСОНОМІЧНІ ЗАСАДИ НАРАТИВНОГО ДИСКУРСУ
}

о. Є. Стрижак

\author{
Національний центр «Мала академія наук України»
}

\begin{abstract}
Складністю інорормаційно-аналітичної діяльності експертів у певній отраслі за різними тематичними профрілями, $є$ проблема накопичення великих обсягів наукової і науково-технічної продукції, що являє собою пасивну розподілену систему знань. Ця проблема великих даних (Big Data), потребує новітніх рішень, що забезпечують інтегративне використання експертами наративу описів усіх документів, які характеризують наукову та науково-технічну продукцію. Одним із механізмів опанування змістовності мережевих документів є наративний дискурс, що реалізується на основі процедур аналізу, структуризації, класифрікації, крітеріалізаці, синтезу й оцінювання тощо. Однак первинним для цих процедур $є$ формування таксономій, що відображають семантичну змістовність кожного документу. Тоді представлення мережевих документів у срорматі наративного дискурсу реалізує підтримку процесів взаємодії експертів. Такий підхід із забезпечення індормаційно-аналітичної діяльності експертів створює умови оптимального оброблення ними великої кількості різнопланових інсрормаційних масивів. На основі таксономічного представлення великих даних для них реалізується компонентна архітектура сервісів підтримки прийняття відповідних рішень.
\end{abstract}

Ключові слова: таксономія, онтологія, наративний дискурс, системи знань, когнітивні сервіси, мережеві документи.

\section{TAXONOMIC PRINCIPLES OF NARRATIVE DISCOURSE}

\section{O. Ye. Stryzhak}

\section{National Center «Junior Academy of Sciences of Ukraine»}

Background. The complexity of information and analytical activities of experts is the problem of accumulation of large volumes of scientific products, which is a passive distributed system of knowledge. This problem of Big Data, requires the latest solutions that will ensure the integrative use experts of narrative descriptions of all documents that reflect the content of scientific results.

Materials and methods. Results. One of the mechanisms for mastering the content of network documents is narrative discourse, which is implemented on the basis of procedures of analysis, structuring, classification, identification of criteria, synthesis and evaluation, and so on. However, the primary for these procedures is the formation of taxonomies that reflect the semantic content of each document. Then the presentation of online documents in the format of narrative discourse implements support for the interaction of experts.

Conclusions. This approach to ensuring the information and analytical activities of experts creates the conditions for optimal processing of a large number of diverse information arrays. On the basis of taxonomic representation of big data for them the component architecture of services of support of decision-making is realized.

Key words: taxonomy, ontology, narrative discourse, knowledge systems, cognitive services, network documents.

\section{ТАКСОНОМИЧЕСКИЕ ОСНОВЫ НАРРАТИВНОГО ДИСКУРСА}

\section{А. Е. Стрижак}

\section{Национальный центр «Малая академия наук Украины»}

\begin{abstract}
Сложностью инорормационно-аналитической деятельности экспертов в произвольной отрасли по различным тематическим профилями является проблема накопления больших объемов научной и научно-технической продукции, которая представляет собой пассивную распределенную систему знаний. Эта проблема больших данных (Big Data), требует новых решений, обеспечивающих интегративное использование экспертами нарратива описаний всех документов, характеризующих научную и научно-техническую продукцию. Одним из механизмов по освоению содержательности сетевых документов является нарративный дискурс, который реализуется на основе процедур анализа, структуризации, классификации, критериализаци, синтеза, оценки и тому подобное. Однако первичным для этих процедур является формирование таксономий, отражающее семантическую содержательность каждого документа. Тогда представления сетевых документов в фрормате нарративного дискурса реализует поддержку процессов взаимодействия экспертов. Такой подход по обеспечению информационно-аналитической деятельности экспертов создает условия оптимальной обработки ими большого количества разноплановых инорормационных массивов. На основе таксономического представления больших данных для них реализуется компонентная архитектура сервисов поддержки принятия соответствующих решений.
\end{abstract}

Ключевые слова: таксономия, онтология, нарративный дискурс, системы знаний, когнитивные сервисы, сетевые документы. 
Вступ. В основі аналітичної діяльності експертів за будь-яким тематичним напрямом, лежить аналіз інформаційних ресурсів (IP), наративи яких за змістом відображають властивості й функціональність певної продукції та операціональних процесів [1, 2]. Таки наративи можна розглядати як сукупності пасивних систем знань, що тільки відображають певні факти, процеси та операціональні стани, але не мають правил їх активного використання. Однак мережецентризм, що сьогодення визначає умови трансдисциплінарного використання IP, вимагає реалізовувати не тільки їх активне використання, а ще й забезпечувати взаємодію безпосередньо між ними. При цьому треба також враховувати постійне оновлення IP, включаючи їхній зміст у процеси активного використання та взаємодії.

Змістовну основу вказаних наративів складають описи наукової і науково-технічної, технологічної, промислової та інших видів продукції, що відображають системи знань, які створюються в процесі людської діяльності. Саме це підтверджує мережецентрична фаза еволюції, у яку світ вступив, і яка функціонально реалізується на засадах трансдисциплінарної взаємодії усіх інформаційних ресурсів і процесів, що утворюють інтерактивну павутину. В середовищі останньої забезпечується накопичення наукових і науково-технічних знань, їхнє інтегроване оброблення, реалізуються комунікації та підтримуються процеси прийняття рішень [1-4].

Відмітимо, що категорія взаємодії включає в себе категорію інтеграції IP. Тут треба розглядати пасивну та активну (трансдисциплінарну) типи інтеграції. Пасивна інтеграція зводиться до простого об'єднання контекстів наративів, що використовуються. Трансдисциплінарна інтеграція (TI) $[5,6]$ здійснюється на основі певних когнітивних процесів (рис. 1.) [5, 7-10], реалізація яких забезпечує активне використання властивостей міжконтекстних зв'язків, множина котрих визначає правила активного використання IP відповідно до їхнього тематичного змісту.

Головним проявом зазначеного явища $є$ висока інтенсивність мережевої взаємодії, що реалізується на основі трансдисциплінарно зв'язаних між собою процесів виробництва, оброблення, зберігання, розповсюдження та використання великих обсягів інформації і знань. Нагальна потреба відповіді на цей глобальний виклик стимулювала нові підходи до оперування надвеликими масивами інформації і призвела до виникнення концепції Великих Даних (Big Data) [5, 11].
Проте без наявності відповідних інформаційноаналітичних сервісів, системи знань $є$ пасивною компонентою інформаційного простору. Їхнє оброблення носить частковий характер, що не відображає їх інтегративний характер і суттєво знижує ефективність використання. Для їхнього оброблення необхідне існування інтелектуальних когнітивних сервісів інтегрованого аналітичного оброблення всього наративу знань. Такі сервіси повинні обов'язково забезпечувати процеси семантичного контент-аналізу за всіма системними складовими та структурне відображення його результатів, а саме: їхні властивості, функціональні характеристики та міжсистемні зв'язки, включаючи посилання на операціональні процеси 3 урахуванням різноманітних умов розвитку.

Більш того, вказані когнітивні сервіси повинні бути орієнтовані на оброблення інтегрованої інформації, що формується у процесах взаємодії з IP на основі міжконтекстних зв'язків. Множинність цих міжконтекстних зв'язків представляється у вигляді таксономій $[5,12,13]$, що в свою чергу можуть бути представлені у вигляді математичних висловлювань $[3,8,14]$. Отже, на основі множин таксономій, як множини математичних висловлювань, можуть бути визначені логічні метарамки представлення процесів інтеграції IP на більш високому рівні абстракції. А це дозволяє визначити процес інтеграції на основі встановлення міжконтекстних зв’ язків як трансдисциплінарний [2, 5-9, 13].

Суттєвою ознакою таксономій є той факт, що вони індуктивні, утворюють непусту множину нерухомих точок [3, 14], та такі, що до їхніх елементів може бути застосована аксіома вибору [3]. На цій основі реалізуються інтелектуальні засоби оброблення інформаційних ресурсів, до яких у першу чергу треба віднести: контент-аналіз і структурування мережевих інформаційних масивів, агрегування їхніх контекстів до контуру оброблення інформації; недосконалість механізмів інтеграції засобів видобування та формування знань про керовані процеси; виявлення та ідентифікація латентних зв'язків.

Засоби, що спроможні підтримувати процеси конструктивного вирішення вказаних проблем, носять трансдисциплінарний характер і визначаються на основі розв'язання таких категорій когнітивних мета завдань - структуризації; аналізу/ виділення проблеми; синтезу; вибору. Когнітивні засоби забезпечують використання всієї контекстної зв'язності інтегрованого наративу інформаційного простору економіки знань. Взаємодія 


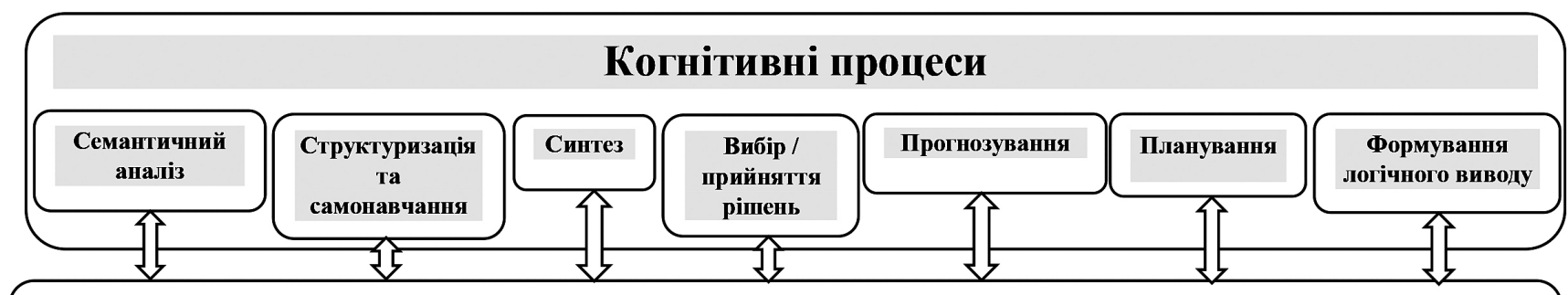

\section{Інформаційні ресурси}

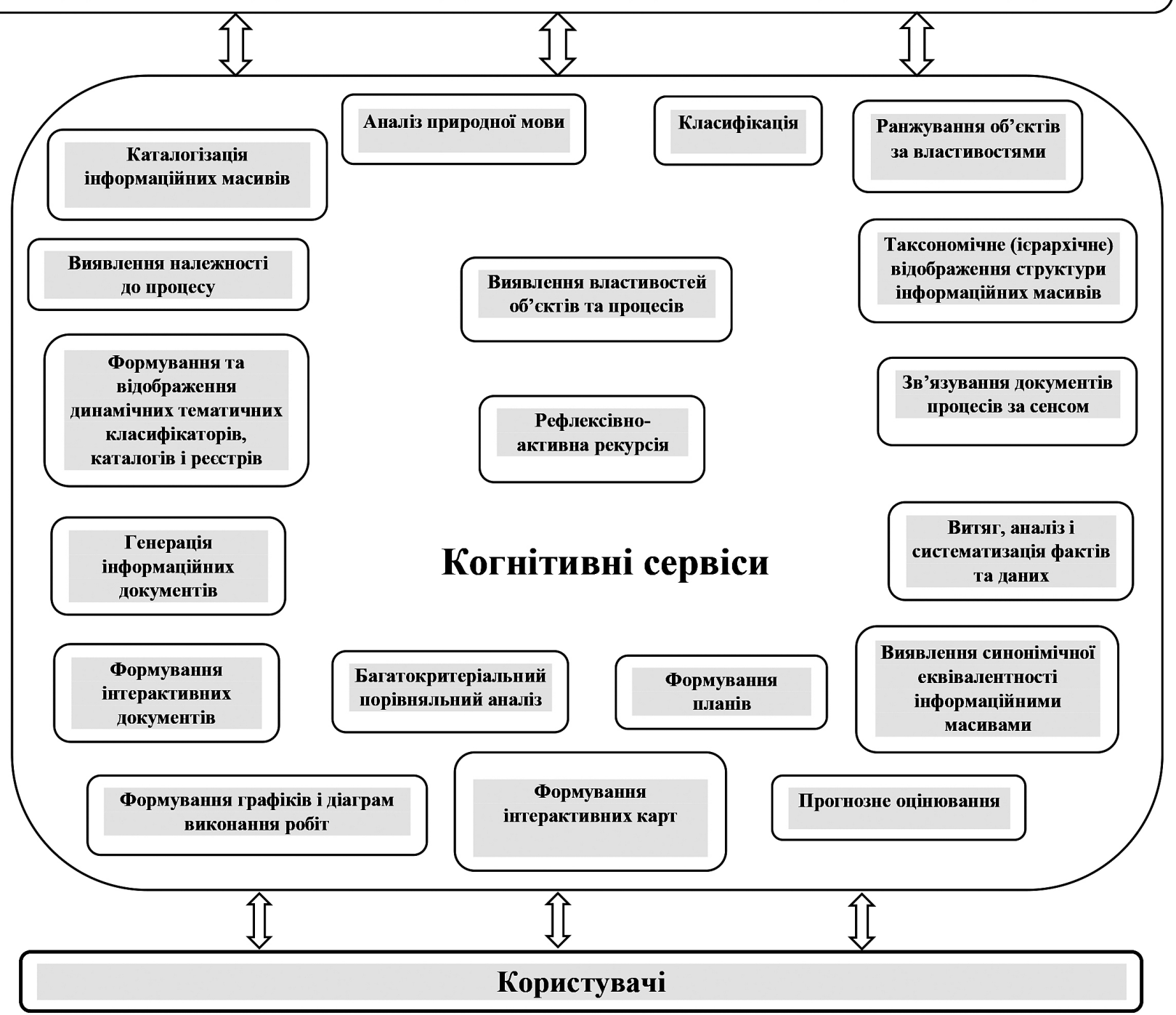

Рис. 1. Схема взаємодії з інформаційними ресурсами на основі когнітивних сервісів

експертів і спеціалістів з інтегрованим наративом описів різноманітних систем знань, реалізується на основі когнітивних засобів, що забезпечують трансдисциплінарні перетворення всіх документів, що його складають, в інтерактивний вид.

Такий підхід спроможний забезпечити формування сучасного інформаційно-аналітичного середовища для забезпечення прийняття відповідних рішень щодо конструктивного використання науково-технічної продукції (НТП) за різними тематичними профілями.

Результати та їх обговорення. Таксономія, як система структурного аналізу наративу. В сучасних умовах в якості бази для створення єдиного 
інформаційного простору доцільно розглядати процедури трансдисциплінарних онтологій $[5,7,2$, 16]. У даному випадку, структурне відображення як окремого документу, так і досить великої за обсягом колекції документів, найбільш конструктивно реалізувати у вигляді певної множини таксономій. При цьому, під цифровою колекцією документів розуміється процедура систематизації документальних мережевих ресурсів (big data sources) множиною природномовних текстів, що об'єднані за однією ознакою або сукупністю ознак (мовних, понятійних, прагматичних, часових, стильових, функціональних, інтенціональних тощо). Цифрові колекції документів створюють умови для проведення лінгвістично-семантичного аналізу текстів, що дозволяє автоматично знайти фрази, в яких використовуються терміни в текстах відповідних документів.

Таксономія документів (Т) розглядається як певний результат застосування когнітивної процедури структуризації текстових масивів на основі системологічного представлення їхньої термінологічної системи в ієрархічному вигляді. Результатом застосування процедури таксономізації текстів $€$ представлення їхньої структури у вигляді графа без циклів [14, 15], кожна вершина містить відповідні контексти, зміст яких складають семантичні описи та характеристики відповідних термінів і словосполучень.

Таксономія забезпечує виділення класифікаційних одиниць текстового масиву, що характеризують його семантику та призначення, а також відображає упорядкованість взаємодії між термінологічними конструкціями. Таксономічне представлення певної сукупності документів, що характеризують різноманітні процеси, створює технологічні умови для формування цифрової колекції.

Зазначимо, що довільну таксономію, як множинне ієрархічне впорядкування термінів певної колекції документів, можна представити у вигляді зростаючої пірамідальної мережі [15].

Класично, відповідно до визначення, запропонованого V. Gladun [15], під пірамідальною мережею $\Psi$ розуміється ациклічний орієнтований граф $\Psi$ $=(\mathrm{X}, \mathrm{E})$ із відсутніми вершинами, які мають одне ребро, що заходить. $\mathrm{X}=\left\{x_{i} \mid i=\overline{1, n_{1}}\right\}$ множина вершин мережі (концепти документу), де $\mathrm{x}_{\mathrm{i}}$ - довільна вершина мережі, $n_{1}$ - кількість вершин у мережі. $E=\left\{e_{i} \mid i=\overline{1, n_{2}}\right\}$ - множина ребер мережі, де $e_{i}$ - довільне ребро, $n_{2}-$ кількість ребер у мережі.
Вершини, які не мають дуг, що заходять, утворюють термінальні концепти (термінали), інші вершини утворюють класи концептів (класи). Термінали відповідають окремим значенням ознак із описів об’єктів. Класи відповідають комбінаціям значень ознак, що ідентифікують об'єкт у цілому, або відповідним спільним частинам описів декількох об’єктів. Множина вершин пірамідальної мережі — це множина $X$ концептів пірамідальної мережі, де кожен концепт хј являє собою певну мовну лексичну одиницю:

$$
\mathrm{x}_{\mathrm{i}}=\text { поняття } \mid \text { слово } \mid \text { фраза. }
$$

Підграф пірамідальної мережі, що включає певну вершину $\boldsymbol{C} \in \boldsymbol{X}$ та всі вершини, з яких існує шлях до неї, називається пірамідою вершини $C$. Вершини, що входять до піраміди вершини $C$, утворюють їі субмножину, що позначимо як $X_{c}$. Вершини, що належать до $X_{c}$ та безпосередньо зв'язані з С ребром будемо називати 0-субмножиною цієї вершини. Множина вершин, до яких входить вершина $C$, називається ії супермножиною, що позначимо як $\overline{\boldsymbol{X}_{\boldsymbol{c}}}[3,15]$.

Зрозуміло, що $\boldsymbol{X}_{\boldsymbol{c}} \cup \overline{\boldsymbol{X}_{\boldsymbol{c}}}=\boldsymbol{\Psi}_{\boldsymbol{c}}$, де $\boldsymbol{\Psi}_{\boldsymbol{c}}$, - пірамідальна мережа, що створено всіма концептами, які мають спільні ребра із вершиною $C$.

Такі таксономічні структури у вигляді зростаючої пірамідальної мережі, реалізують трансдисциплінарну категорізацію контекстів, як системологічне, динамічне формування класів контекстних описів на основі утворення стійких бінарних сполучень між визначеними термінами, фразами та словоформами. Відображення семантичної зв'язності понять та їхніх контекстів, що відображають відповідні інформаційні ресурси, у вигляді пірамідальної мережі $\Psi \in$ н необхідною умовою формування множини таксономій, які спроможні відображати структурне різноманіття всього наративу всіх текстових масивів, котрі в свою чергу утворюють указані ресурси. Зазначені пірамідальні мережі $\boldsymbol{\Psi}$ унівалентні [16] таксономічним структурам $T$ :

$$
\Psi \cong T
$$

Тоді завжди існують унівалентні між собою непусті множини таксономій і пірамідальних мереж певного наративу. Такі структурні відображення будемо називати наративним таксономічним різноманіттям (НТР):

$$
\left(\left\{\boldsymbol{T}_{j} \mid \mathrm{j}=\overline{1, m}\right\} \cong\left\{\Psi_{\mathrm{i}} \mid \mathrm{i}=\overline{1, n}\right\} \mid \mathrm{j} \geq \mathrm{i}, \mathrm{m} \geq \mathrm{n}\right)
$$


Тобто довільна таксономія $T$ може бути створена на основі певної кінцевої множини пірамідальних мереж виду - $\left\{\Psi_{\mathrm{i}} \mid \mathrm{i}=\overline{1, n}\right\}$, що будьмо називати наративним таксономічним різноманіттям і позначати - $\mathrm{T}_{\text {HР }}$ :

$$
T_{j} \cong \bigcup_{i=1}^{n} \Psi_{i}
$$

Вирази (1) - (4) відображають той факт, що певна таксономія $T$ формується наборами концептів, які утворюють непусту множину пірамідальних мереж виду $\Psi=(X, E)$ деякого наративу. Отже, множина $\left\{\Psi_{\mathrm{i}} \mid \mathrm{i}=\overline{1, n}\right\}$, що визначається множиною концептів $X$, є семантичним структурним відображенням наративного представлення інформаційних ресурсів. На основі цього можна стверджувати, що концепти $X$ наративного таксономічного різноманіття виду (4) визначають деяке термінополе ТP цього наративу, термінополе якого має відкритий характер. Тобто довільна таксономія Т може поповнюватися новітніми пірамідальними мережами виду (3), що мають додаткові концепти $\boldsymbol{x}_{\boldsymbol{k}} \mid \boldsymbol{k}>\boldsymbol{n}$.

Множина ребер $E$ пірамідальної мережі $\boldsymbol{\Psi}$, визначає тільки наявність бінарної зв’язності між їі концептами. Орієнтація ребер дозволяє групувати концепти за такими категоріями як термінальний, клас, субмножина, супермножина, концент.

Термінальний концепт $x_{t}$ не має вхідних стрілок, тобто він не $є$ комутативним відносно бінарного ребра $\boldsymbol{e}_{\mathrm{i}}$ :

$$
\left(x_{t} e_{\mathrm{i}} x_{i}\right) \neq\left(x_{i} e_{\mathrm{i}} x_{t}\right)
$$

Клас $\boldsymbol{X}^{\boldsymbol{k} \boldsymbol{l}}$ визначає усі концепти, що належать певному категоріальному концепту $x_{i}$, що не $\epsilon$ термінальним:

$$
X^{K l}=\left\{x_{i} e_{\mathrm{i}} X^{K l} \mid\right\}
$$

Субмножина $X^{s b}$ визначає концепти, для яких вказаний (базовий) концепт $x_{i} \in$ категоріальним, даний концепт не може бути термінальним:

$$
\begin{aligned}
& X_{i}^{s b}=\left\{<x_{i}^{j} e_{i}^{s b} e_{i+1}^{s b} x_{(i+1)}^{j}\right. \\
& e_{(i+2) \cdots e_{(i+k-1)}^{s b} x_{(i+k)}^{j}>}^{s b} \\
& \mid(i=\overline{\mathbf{1}, m}),(k=\overline{l, m}), \\
& (\mathrm{j}=\overline{\mathbf{1}, l}),
\end{aligned}
$$

де $\boldsymbol{e}_{\boldsymbol{i}}^{\boldsymbol{s} \boldsymbol{b}}$ - ребро яке позначено стрілкою, що входить у базовий концепт $x_{i}$.

Супермножина визначає концепти, що є категоріальними для вказаного (базового) концепту та можуть бути термінальними:

$$
\begin{aligned}
& X_{i}^{\text {sup }}=\left\{<x_{i}^{j} e_{i}^{\text {sup }} e_{i+1}^{\text {sup }} x_{(i+1)}^{j}\right. \\
& \left.e_{(i+2)}^{\text {sup }} \ldots e_{(i+k-1)}^{\text {sup }} x_{(i+k)}^{j}>\right\} \\
& \mid(i=\overline{1, m}),(k=\overline{l, m}),(j=\overline{1, l})
\end{aligned}
$$

де $\boldsymbol{e}_{\boldsymbol{i}}^{\boldsymbol{s u p}}$ - ребро, що позначено стрілкою, яка виходить із базового концепту $x_{i}$.

Як можна бачити з виразів (7) і (8) ребра $\boldsymbol{e}_{\boldsymbol{i}}^{\boldsymbol{s u p}}, \boldsymbol{e}_{\boldsymbol{i}}^{\boldsymbol{s b}}$ мають протилежну орієнтацію. Виходячи з цього можна визначити таке:

$\boldsymbol{e}_{\boldsymbol{i}}^{\boldsymbol{s u p}}+\boldsymbol{e}_{\boldsymbol{i}}^{\boldsymbol{s} \boldsymbol{b}}=\boldsymbol{e l}$, де $e-$ ейлеров підграф, для сильно зв’язаних концептів.

$\boldsymbol{e}_{\boldsymbol{i}}^{\boldsymbol{s u p}} \times \boldsymbol{e}_{\boldsymbol{i}}^{\boldsymbol{s} \boldsymbol{b}}=\boldsymbol{E} \boldsymbol{l}$, де $E l-$ множина ейлерових шляхів у пірамідальної мережі $\boldsymbol{\Psi}_{\boldsymbol{i}}$.

Концент визначає всі категоріальні та термінальні концепти, що знаходяться від вказаного хі на певній відстані, значення якої є цілим числом і дорівнює кількості бінарних ребер, що їх з’єднує: $\left(\sum_{1}^{n} e_{i} \cdot \mid \mathrm{e}=1\right)$.

$\boldsymbol{X}_{\boldsymbol{i}}^{\boldsymbol{k} \boldsymbol{c}}=\left\{\boldsymbol{x}_{\boldsymbol{i}} \times \prod_{1}^{\boldsymbol{l}} \sum_{1}^{\boldsymbol{n}} \boldsymbol{e}_{\boldsymbol{i}} \boldsymbol{x}_{\boldsymbol{j}}\right\}$ де $l-$ відстань від концепту $x_{i}$ до концепту $x_{j}, n-$ кількість бінарних ребер від кожного концепту.

Виходячи з того, що пірамідальна мережа $\boldsymbol{\Psi}_{\boldsymbol{i}}$, за визначенням є орграфом без циклів, у неї відсутні ейлерови підграфи. Проте штучно можна утворити непусту множину ейлерових шляхів.

Визначена таксономічна функціональність забезпечує технологічну основу ефективного оброблення великих обсягів інформаційних ресурсів, що притаманні сучасному інформаційному простору. Усі IP, що його складають, мають мережевий характер. Тому таксономія складає технологічну основу забезпечення процесу категоризації контекстів усіх IP на основі системологічного, динамічного формування класів контекстних описів, що складають увесь наратив цих ресурсів.

Однак для цього треба забезпечити між термінами, словами, фразами та словоформами утворення стійких бінарних сполучень. Ці сполучення крім відображення таксономічних структур типу (1) - (8), повинні реалізовувати зв’язність між усіма системними компонентами таксономічних 
структур і забезпечувати їхнє впорядкування при проведенні аналітичннх досліджень.

Для цього введемо групу гіпервластивостей, що забезпечують зв'язування та динамічну зміну впорядкування контекстних описів наративу IP. Це можна досягнути на основі використання рефлексії $-\mathcal{R}_{f}$, рекурсії $-\mathcal{R}_{k}$ та редукції $-\mathcal{R}_{d}$ [2, 30, 39, 40]. Зазначені гіпервластивості мають трансдисциплінарний і когнітивний характер [5, $6]$ та утворюють замкнуту множину $\mathcal{R} 3$ :

$$
\mathcal{R} 3=\left\{\mathcal{R}_{f}, \mathcal{R}_{k}, \mathcal{R}_{d}\right\} .
$$

Застосування гіпервластивостей вказаної множини утворює умови застосування онтологічного підходу в процесах аналітичного дослідження мережевих слабоструктурованих чи взагалі неструктурованих IP [5, 7, 14-16]. Будь-яка таксономічна система формується на основі структурованого представлення предметної області її застосування. Зазвичай основу структурування складають класи об'єктів [16], на які умовно розбивається множина всіх понять, властивості яких визначають семантику предметної області. Безпосередньо властивості концептів за рахунок утворення бінарних зв'язків із гіпервластивостями множини $\mathcal{R} 3$, дозволяють визначити множину класів відношень між ними.

Утворення кожного такого класу реалізується наступним образом. Спочатку кожен такий клас іменується та далі наповнюється концептами документу, що мають бінарне відношення з іменем класу на основі утворення стійкого бінарного відношення між його властивістю та одним з гіпервідношень замкнутої множини $\mathcal{R} 3$. Таке відношення має вигляд:

$$
<\boldsymbol{r}_{k l}^{t}, \mathcal{R}_{g},>\left|\boldsymbol{r}_{k l}^{t} \in \mathcal{R}_{k l}^{T}\right| \mathcal{R}_{g} \in \mathcal{R} 3, g \in\{f, c, d\}
$$

де $T$ - тип концепту, $t$ — властивість типу, $k c$ спеціальний індекс, що визначає концепт.

Множинність наведеного бінарного відношення визначається тим, що воно зв'язує деякий набір концептів з ім'ям класу, що утворює даний набір концептів.

$$
\left\{x_{k l}^{t}<\boldsymbol{r}_{k l}^{t}, \mathcal{R}_{g}>X_{k l}^{T}\right\}
$$

де $X_{k l}^{T}$ - ім'я класу, що був утворений набором концептів $x_{k l}^{t}$
Класи концептів також є елементами таксономії документу та можуть утворювати новітні класи:

$$
\left\{Y_{k l}^{t_{i}}<\mathcal{R}_{k l}^{T^{t_{j}}}, \mathcal{R}_{g}>X_{k l}^{t_{n}}\right\} \cong \mathbb{X}_{k l}^{T_{l}}
$$

Представлення ім'я класу виду $X_{k c}^{t_{n}}$ каже, що цей клас утворено з концептів, які маю $t_{n}$ властивість.

Над кожним класом, як елементом таксономії певної складності, визначається бінарне відношення ї часткової упорядкованості. Уся сукупність класів утворює повну таксономічну систему документу над якою може бути визначена повна часткова упорядкованість. Тоді коренева вершина таксономії усього документу є нерухомою точкою множини, що включає всі концепти документу. Таксономічна система, яка утворюється на основі вказаної множини концептів із нерухомою точкою $[3,14]$ також є повною. Для повної таксономічної системи однією з нерухомих точок є ім'я цього документу.

Більш того, повна таксономічна система є структурованим об'єктом і може розглядатися з позицій теорії гомотопичної теорії типів $[48,49]$. Таксономія, як структурований об'єкт, утворюється на основі стійких бінарних сполучень між концептами документів. Отже, її можна також розглядати як бінарне дерево [3, 14], що є гомотопичним типом i характеризується гіпервластивістю унівалентності [16]. Це дозволяє нам стверджувати, що таксономія довільного документу унівалентна усьому простору бінарних дерев, які можна утворити з його концептів.

$$
T \cong B_{D}
$$

де $B_{D}$ - довільне бінарне дерево.

Будь-яка таксономічна система $T$, формується на основі структурованого представлення предметної області її застосування. Зазвичай основу структурування складають класи об'єктів [17], на які умовно розбивається множина всіх понять, властивості яких визначають семантику предметної області. Безпосередньо властивості концептів дозволяють визначити множину відношень між ними. Множинні бінарні відношення впорядкованості складають тип гіпервідношень, що мають властивості унівалентності [16] та за рахунок цього забезпечують формування з класів концептів різних таксономічних структур. 
Слід зазначити, що повна таксономічна система $T$ формується на основі виділення певної підмножини концептів $X$, що мають загальну характеристичну властивість. Така властивість може бути унарною для кожного концепту, проте при визначенні зазначеного класу, як складного концепту, така властивість дозволяє визначити над усіма концептами класу множинне бінарне відношення (бути елементом класу). При цьому слід зазначити, що унарна властивість, яка є загальною для множини концептів предметної області, може інтерпретуватися як ознака цих концептів, або як критерій для вибору концептів даного класу.

Так, під час вибору концептів-кандидатів для формування певної категорії - класу (class), спочатку визначається властивість-ознака, на підставі якої дана категорія може бути представлена як складний концепт. При цьому, включення до категоріїкласу конкретного простого концепту, або поняття 3 менш складною структурою грунтується на унарній властивості-критерії, що характеризує його, та $є$ загальною для всіх концептів цієї категорії-класу. Зазначена загальна властивість дозволяє визначити для даної категорії бінарне відношення «частина-ціле», що також задає часткову впорядкованість [3, 14] над усіма концептами сформованої категорії класів.

Отже, множина бінарного відношення часткової упорядкованості може бути задана на основі бінарного відношення «частина-ціле», що може бути переписано у вигляді множинного відношення — «група об’ єктів — об’єКт». Поняття «група об’єктів» визначає ім’я складного концепту-класу, що є таксономічною категорією для розглянутої предметної області. Вибір концептів для їхнього включення в таксономічну категорію за загальними семантичними властивостями можемо розглядати як об’єднання одноелементних множин, де кожна така множина визначена конкретним концептом предметної області з обраною загальною для них властивістю-критерієм.

Конструктивність застосування процедури вибору [3, 5, 4] проявляється можливістю точного визначення необхідного елемента для формування таксономії. Перевага критеріального вибору в даному випадку не залежить від методу ранжування. Таксономія задається концептами із загальною властивістю, над якими визначається множинне бінарне відношення часткової упорядкованості виду $\mathrm{x}_{i}^{\mathrm{j}} \tilde{\mathrm{p}} \mathrm{x}_{1}^{\mathrm{k}} \stackrel{\alpha}{\longrightarrow} \mathrm{x}_{\mathrm{i}}^{\mathrm{j}} \mathrm{px}_{1}^{\mathrm{k}}$, в якому концепти мають властивості часткової впорядкованості - $\tilde{\mathrm{p}}$ та лінійної впорядкованості — p [3, 14].
Таксономія $T$ може бути визначена для будь-якого складного концепту, тобто за замовчуванням вона може бути утворена бінарним відношенням лінійної упорядкованості «частина-ціле». Відношення «частина-ціле» може бути розширено до множинного відношення «група об’ єктів - об’єкт» і далі до «бути елементом класу» та/або «бути елементом категорії» [8, 12].

Гіпервідношення Gr, задане над множинними бінарними відношеннями упорядкованості, що визначають таксономію, дозволяє сформувати предикативні вирази на основі її концептів із заданим

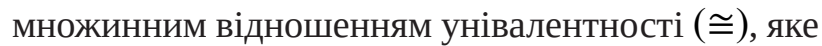
поглинає відношення часткової упорядкованості. Це поглинання одного гіпервідношення іншим має вигляд:

$$
\begin{aligned}
& \left(\mathrm{x}_{\mathrm{i}}^{\mathrm{j}} \tilde{\mathrm{p}} \mathrm{x}_{1}^{\mathrm{k}} \stackrel{\alpha}{\longrightarrow} \mathrm{x}_{\mathrm{i}}^{\mathrm{j}} \mathrm{px}_{1}^{\mathrm{k}}\right) \vee(\cong)=(\cong) \vee\left(x_{s}^{j} \tilde{p} x_{l}^{k}\right) \rightarrow \\
& (\cong) \vee x_{s}^{j} p x_{l}^{k}
\end{aligned}
$$

Фактично вказане унівалентне поглинання визначає рівні еквівалентності таксономічних систем, які відображають документи, що мають спільні властивості. За результатами формування множини класів концептів таксономічної системи та за допомогою унівалентності отримуємо метатаксономію, концептами якої є задане множинне бінарне відношення «частина-ціле». Така таксономія може мати складну структуру низхідних ієрархій. Кожний складник являє собою клас концептів, що мають як мінімум одну загальну семантичну властивість [51-53]:

$$
\begin{aligned}
& \operatorname{Pr}\left(\mathrm{x}_{1}, \ldots, \mathrm{x}_{\mathrm{n}}\right)=0 \Rightarrow \exists \mathrm{T} \subseteq \breve{\mathrm{T}}: \forall \mathrm{x} \in \mathrm{X} \exists \mathrm{Y} \\
& \subseteq \mathrm{X}: \mathrm{T}=\mathrm{YGrx},
\end{aligned}
$$

де $Y$ - множина всіх можливих множин концептів $X$ таксономічної категорії $\breve{\mathrm{T}}$, а х $i-$ один із концептів цієї множини.

Отже, відношення унівалентності визначає взаємодію між концептами кожної таксономії, що виділена з різних класів концептів предметної області та, відповідно, дозволяє визначити нові види таксономічних систем.

Зазначений підхід (1) - (15) дозволяє реалізувати таксономічне представлення наративу цифрової колекції усієї сукупності документів, що розробляються та використовується під час створення новітньої продукції. 
Таксономічний характер наративного дискурсу. Представлення документів у вигляді наративів, що являють собою послідовність викладу фактів і подій, як певних об’єктів у творі, визначає їх як пасивні системи знань. Однак над усіма об'єктами текстових наративів можна визначити процедури виділення описів цих фактів і подій у вигляді окремих контекстів [5, 7, 8, 13]. Тоді отримуємо множини об'єктів, що є концептами, та множини об’єктів, які є класами. Таке розбиття наративного тексту на складові — концепт, клас, контекст, сенс тощо, визначає їх здатність до взаємодії.

Здатність складових наративу до взаємодії будьмо визначати як дискурс, що є когнітивно-коммунікативним актом, який одночасно реалізує бачення реального світу та його уявлення $[7,18]$. Однією з властивостей дискурсу є можливість відображати зв'язність двох і більше наративів. Наявність вербально активних когнітивних процедур оброблення знань $[5,9,10,13]$, що забезпечують їхню систематизацію, а саме - аналіз, структуризацію, класифікацію, крітеріалізацію, синтез, оцінювання тощо, визначається як наративний дискурс $[2,9,18]$.

Отже, можливо визначити певну когнітивну процедуру багатоетапного послідовного перетворення первинної структури наративу тексту в онтологічний вигляд на основі виділення таксономічних систем виду $T$. Така процедура забезпечує автоматичне перетворення текстового наративу, що визначається впорядкованими на основі певних правил синтаксису $\Lambda_{\mathrm{s}}$, які задаються над концептами $\mathbf{x}_{\mathbf{i}} \in \boldsymbol{X}$ таксономією $T$, тезаурусом $T_{i}$ онтологією О. Результат застосування процедури - виявлення концептів виду $x_{i}$, 3 яких складаються класи об’єктів предметної області (зокрема, їх назви), виявлення первинних міжконтекстних зв'язків і таксономічне представлення семантики тексту.

На основі правил (1) - (15) можна стверджувати, що фактично таксономія визначає наративний дискурс між текстами, як системами знань. Більш того таксономія, як семантична структура представлення наративного тексту в якості системи знань, виявляє у наративі множину гіпервластивостей виду (9), а саме: рефлексію $-\mathcal{R}_{f}$, рекурсію $-\mathcal{R}_{k}$ і редукцію $-\mathcal{R}_{d}$.

Правила (10) - (12) визначають характер взаємодії цих систем знань у форматі наративного дискурсу. Так при значенні у виразі (10) параметру $\mathrm{g}=\mathrm{f}$, отримуємо множинність бінарних утворень між контекстами певних концептів із різних класів у такому вигляді:

$$
<\boldsymbol{r}_{k l}^{t}, \mathcal{R}_{f},>\left|\boldsymbol{r}_{k l}^{t} \in \mathcal{R}_{k l}^{T}\right| \mathcal{R}_{f} \in \mathcal{R} 3
$$

Кожне значення властивості типу t, реалізує утворення множини бінарних відношень між контекстами концептів із різних класів. Однак кожен клас за рахунок наявності зв' язків між контекстами концептів може бути представленим у вигляді таксономії $T$. Тобто створюється супермножина таксономій $\breve{T}$ між елементами якої встановлено множинне відношення рефлексії. А відповідно до правила (8) така супермножина може об'єднувати категоріальні класи. Тоді в супермножині таксономій наративного дискурсу документів може бути виділено множина ейлерових підграфів Esup*. Більш того, відношення рефлексії може утворювати непусту множину з ейлерових циклов, що включають у себе непусті класи концептів. Цей ейлеров підграф відображає наявність міжконтекстних зв'язків між різними концептами з різних класів. Отримаємо набір вербально активних когнітивних процедур обробки знань, що й утворюють наративний дискурс.

Для того щоб позбавитися множинності типу «один концепт - група концептів» над супермножиною $\check{T}$ (рис. 2) задається гіпервластивість рекурсії, яка забезпечує виділення з неї лінійно упорядкованих ланцюгів концептів із одного та більш класів. Тобто, якщо рефлексія визначає таку гіллясту структуру множинності та концентричний вигляд наративного дискурсу, то рекурсія представляє його у вигляді певного ломаного відрізку.

Цей відрізок має вигляд правила (7) та утворюється елементами підмножини $\mp$, що суворо належить супермножини $\check{\boldsymbol{T}}: \boldsymbol{T} \subset \check{\boldsymbol{T}}$.

Так усі концепти, що представлено у вигляді пірамідальної мережі $\boldsymbol{\Psi}$ на рис. 1 , утворюють супермножину Т̆. На рис. 2 представлено приклад формування однієї з таксономій підмножини $\mp$, елементи якої можуть бути виділені рекурсивно на засадах застосування гіпервідношення $R_{k}$, до контекстів концептів, які фактично утворюють кортеж.

У даному випадку з підмножини $\mp$ рекурсівно виділено субмножина $\boldsymbol{X}^{\boldsymbol{s} \boldsymbol{b}}$, яка за правилом (7), визначає концепти, для яких вказаний (базовий) концепт $x_{16} \in$ категоріальним, концепт $x_{1}$ може бути й термінальним.

Процес редукції (рис. 3) полягає в послідовному виділенні з тексту наративу концептів, які конструктивно визначають глосарій ПдО, зв'язків (відношень) між об'єктами, що визначає умови формування таксономій ПдО та рефлексівних атри- 


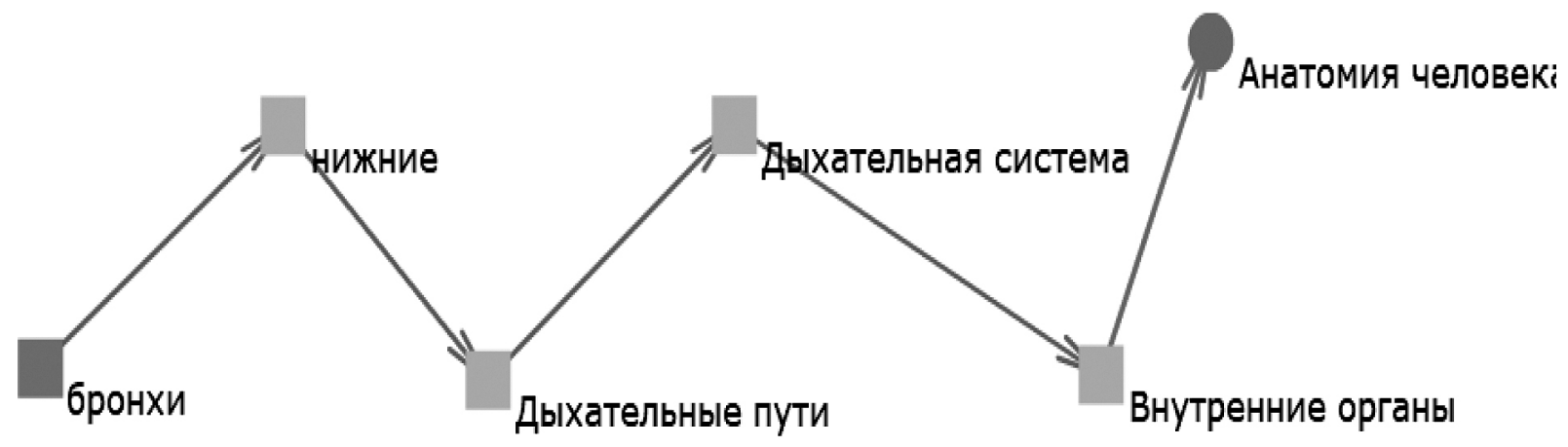

Рис. 2. Рекурсивно утворена таксономія наративного дискурсу на основі таксономії наративу «Анатомія людини»

бутів концептів, які в подальшому забезпечують визначення інтерпретуючих функцій для кожного концепту. Фактично підмножина $\mp$ є проекцією супермножини $\check{T}$ на лінійно упорядкованих міжконтекстних зв'язків, що були встановлені між елементами супермножини $\check{T}$.

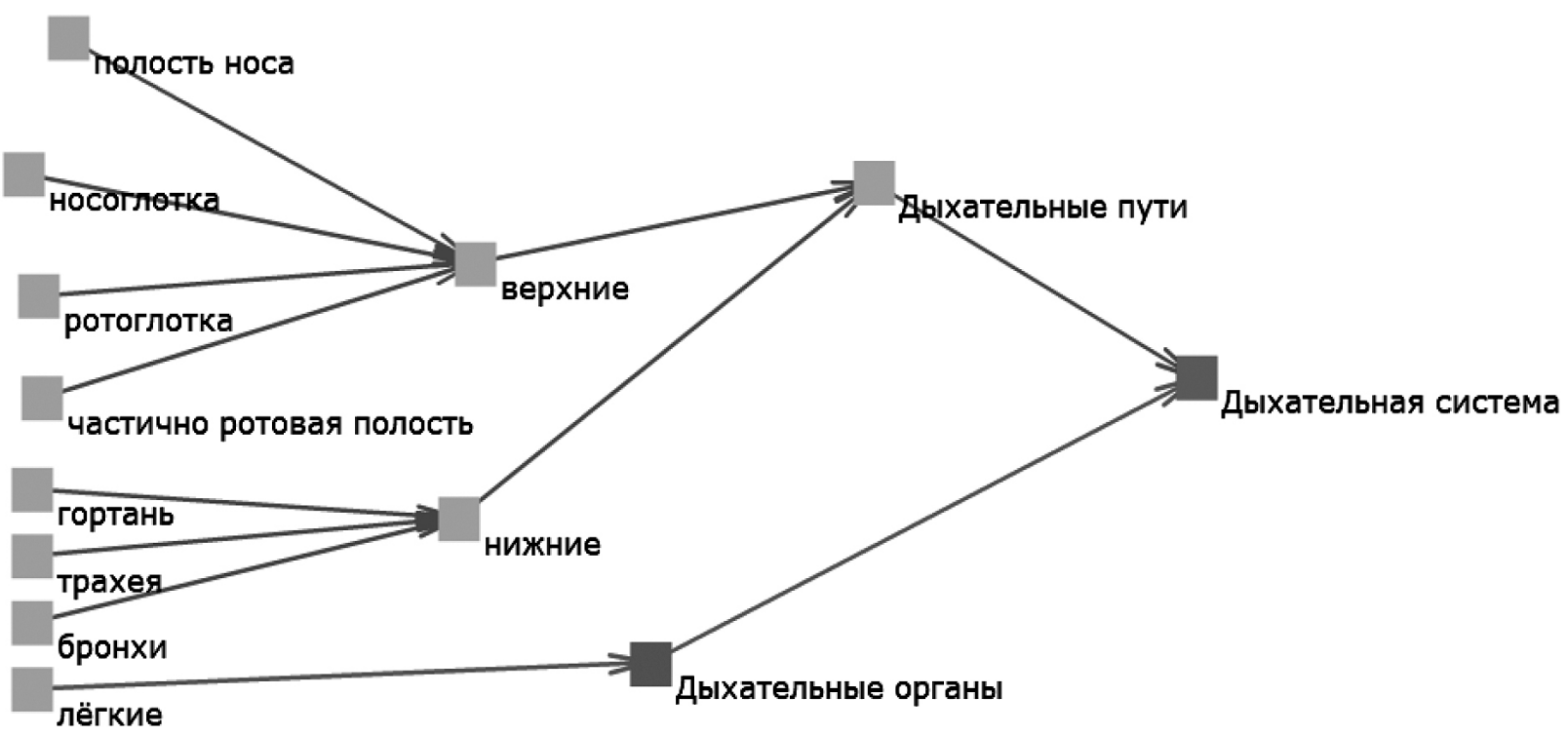

Рис. 3. Застосування до поняття «Дыхательная система», наративу «Анатомія людини», рекурсивної редукції

Конструктивно, редукція $\mathcal{R}_{d}$ може бути застосовано для виділення субмножин виду $\boldsymbol{X}^{\boldsymbol{s} \boldsymbol{b}}$ за

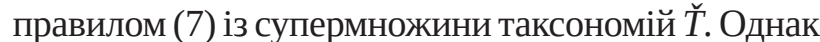
також можливе її застосування й для виділення суперпідмножини виду $\boldsymbol{X}_{\boldsymbol{i}}^{\text {sup }}$ за правилом (8) із супермножини таксономій $\breve{T}$.

Усі ці перетворення наративу тексту документів у наративний дискурс можна представити у вигляді системи правил [5].

Перетворення множини $X$ концептів пірамідальної мережі $\boldsymbol{\Psi}$, що утворює супермножину таксономій $\breve{T}$ у підмножину концептів $Y$ реалізується на основі унівалентності $\boldsymbol{\Psi}$ супермножині таксономій $\breve{T}$ :

$$
F_{\mathcal{R} 3}: X \rightarrow Y
$$

Перетворення (16) можна представити у рекурсивному вигляді:

$$
\boldsymbol{F}_{\mathcal{R} 3}(X)=\left\{\begin{array}{c}
\boldsymbol{F}_{\mathcal{R} 3}(\boldsymbol{X}, \Psi, \mathrm{T}) \rightarrow \mathrm{F}_{i} \\
\left\{X_{i}^{\text {sb }}\right\} \\
\left\{X_{i}^{\text {sup }}\right\}
\end{array}\right.
$$

3 представлення рекурсивного перетворення (17)-(18) можна побачити, що реалізуя застосування відповідного гіпервідношення з множини $\mathcal{R} 3=\left\{\mathcal{R}_{f}, \mathcal{R}_{k}, \mathcal{R}_{d}\right\}$ фактично визначаємо, які типи таксономічних структур будуть визначені для 
взаємодії у форматі наративного дискурсу.

Процес формування супермножини таксономій i оброблення контекстів її елементів будемо визначати як концептографічний аналіз.

Висновки. Мережевий інформаційний простір перенасищено неструктурованими документами. Одним із механізмів відображення їхньої структури $€$ наратавний дискурс. Більш того, наративний дискурс забезпечує міжконтекстну зв'язаність цих документів. Але для цього треба сформувати таксономічну структуру як кожного документу, так і метатаксономію змісту всіх документів, що використовуються.

Таксономічна структура наративного дискурсу, за суттю, забезпечує відображення й інформаційних ресурсів, і процеси взаємодії з ними. Така дуальність забезпечує реалізацію онтологічного подходу до процедур інтеграції усіх системних компонентів і складових операціонального контуру взаємодії експертів і відповідно таких технологічних характеристик:

\section{Література.}

1. Роль инженерной науки и практики в устойчивом развитии общества / М. З. Згуровский, Г. А. Статюха // Систем. дослідж. та інформ. технології. — 2007. — № 1. - С. 19-38.

2. Еволюція управління - від ситуаційного до трансдисциплінарного / Стрижак О. Є., Потапов Г. М., Приходнюк В. В., Чепков Р. І. // Екологічна безпека та природокористування : зб. наук. праць / редкол. : О. С. Волошкіна, О. М. Трофимчук (голов. ред.) [та ін.]. - Міністерство освіти і науки України, Київський національний університет будівництва і архітектури, НАН України Інститут телекомунікацій і глобального інформаційного простору. - Київ, 2019. - Вип. 2 (30). - С. 91-112.

3. Malyshevsky A. Qualitative models in the theory of complex system / Malyshevsky A. - Moscow: Science, Fizmatlit, 1998. - 528 p.

4. О некоторых классах правил выбора предпочтений в задачах принятия решения / В. М. Михалевич // Кибернетика и системный анализ. - 2010. № 6. - C. 140-154.

5. Model of Transdisciplinary Representation of GEOspatial Information / Stryzhak O., Prychodniuk V., Podlipaiev V. / Ilchenko M., Uryvsky L., Globa L. (eds) // Advances in Information and Communication Technologies. UKRMICO 2018. Lecture Notes in Electrical Engineering. - Springer, Cham, 2019. — Vol. 560.
- семантико-лінгвістичний контент-аналіз і відповідна тематична категорізація та класифікація;

• інтеграція інформаційних ресурсів за різними тематичними профілями на основі встановлення міжконтекстних зв’язків інформаційних ресурсів, що аналізуються;

- управління бізнес-процесами із забезпеченням створення персональних інформаційно-аналітичних площадок експертів, підтримки їхньої колективної роботи, публікацій і розповсюдження відповідних повідомлень тощо.

Отже, таксономії відображення мережевих документів у форматі нартивного дискурсу спроможні забезпечити формування мережевих інтерактивних систем знань і подальше їхнє інтегрування у бізнес-процеси. На основі такого підходу можливе створення сучасного інформаційно-аналітичного середовища для прийняття відповідних рішень із створення та конструктивного використання науковотехнічної продукції за різними тематичними профілями.

6. Nicolescu B. Transdisciplinarity - Theory and Practice / Nicolescu B. - Hampton Press, Cresskill, 2008. 320 p.

7. Palagin A. Transdisciplinarity, computer science and development of modern civiliza-tion / Palagin A. // Bulletin of the National Academy of Sciences of Ukraine. - 2014. — № 7. - P. 25-33.

8. Фридман Л. М. Основы проблемологии / Фридман Л. М. — Серия: Проблемология. — М: Синтег, 2001. -228 c.

9. Piaget J. The Psychology of Intelligence / Piaget J. London: Routledge and Kegan Paul, 1951.

10. The Oxford Handbook of Cognitive Engineering / Edited by J. D. Lee, A. Kirlik. — 2013. — doi: 10.1093/ oxfordhb/9780199757183.001.0001.

11. Big Data: A Revolution That Will Transform How We Live, Work, and Think / Mayer-Schönberger V, Cukier K. — Boston: Houghton Mifflin Harcourt, 2013. — 252 p.

12. Шаталкин А. И. Таксономия. Основания, принципы и правила / Шаталкин А. И. - М. : Товарищество научных изданий КМК, 2012. - 600 с.

13. Широков В. А. Язык. Информация. Система : Трансдисциплинарность в лингвистике / В. А. Широков. — K., 2017. - 280 c.

14. Barendregt X. Lambda-calculus. His syntax and semantics / Barendregt X. Moscow: World, 1985. — $606 \mathrm{p}$.

15. Структуризация и анализ данных в растущих пирамидальных сетях / В. П. Гладун, Н. Д. Ващенко, 
В. Ю. Величко, Ю. Г. Ткаченко // Систем. дослідж. та інформ. технології. — 2004. - № 1. - С. 82-92.

16. Voevodsky V. Univalent Foundations of Mathematics / Voevodsky V. / Beklemishev L.D., de Queiroz R. (eds). — Logic, Language, Information and Computation. WoLLIC, 2011. — Lecture Notes in Computer Science. — Berlin: Springer, 2011. — Vol. 6642.

17. Вайсфельд М. Объектно-ориентированное мышление / Вайсфельд М. - С-Пб.: Питер, 2004. - 304 с.

18. David K. E. Modeling Narrative Discourse: Ph.D. thesis / David K. E. — New York City: Columbia University, 2012. - 383 p.

\section{References.}

1. Zhurovskyy, M. Z., Statyukha, H. A. (2007). Rol inzhenernoj nauki i praktiki v ustojchivom razvitii obshhestva [The role of engineering science and practice in the sustainable development of society]. Systemni doslidzhennia ta informatsijni tekhnolohii (Systems research and information technology), 1, 19-38. [In Russian].

2. Stryzhak, O. Je., Potapov, G. M., Pryhodnjuk, V. V., Chepkov, R. I. (2019). Evoljucija upravlinnja — vid sytuacijnogo do transdyscyplinarnogo [The evolution of management - from situational to transdisciplinary]. Ekologichna bezpeka ta pryrodokorystuvannja (Ecological safety and nature management), 2 (30), 91112. Kyiv: Kyivskyj nacionalnyj universytet budivnyctva i arhitektury, NAN Ukrainy Instytut telekomunikacij i globalnogo informacijnogo prostoru. [In Ukrainian].

3. Malyshevsky, A. (1998). Qualitative models in the theory of complex systems. Science. Fizmatlit, Moscow.

4. Mihalevich, V. M. (2010). O nekotoryh klassah pravil vybora predpochtenij v zadachah prinjatija reshenija [On some classes of preference choice rules in decision problems]. Kibernetika i sistemnyj analiz (Cybernetics and Systems Analysis), 6, 140-54. [In Russian].

5. Stryzhak, O., Prychodniuk, V., Podlipaiev, V. (2019). Model of Transdisciplinary Representation of GEOspatial Information / Ilchenko, M., Uryvsky, L., Globa, L. (eds). Advances in Information and Communication Technologies. UKRMICO 2018. Lecture Notes in Electrical Engineering, Springer, Cham, 560, 34-72.
6. Nicolescu, B. (2008). Transdisciplinarity - Theory and Practice. Hampton Press, Cresskill, NJ, USA.

7. Palagin, A. (2014). Transdisciplinarity, computer science and development of modern civilization. Bulletin of the National Academy of Sciences of Ukraine. Kyiv: NAS of Ukraine, 7, 25-33.

8. Fridman, L. M. (2001). Osnovy problemologii [Fundamentals of Problemology]. Ser: Problemologija. Moscow: Sinteg. [In Russian].

9. Piaget, J. (1951). The Psychology of Intelligence. London: Routledge and Kegan Paul.

10. John, D., Kirlik, L. and A. (2013). The Oxford Handbook of Cognitive Engineering. doi: 10.1093/oxf ordhb/9780199757183.001.0001.

11. Mayer-Schönberger, V., Cukier, K. (2013). Big Data: A Revolution That Will Transform How We Live, Work, and Think. Boston, MA: Houghton Mifflin Harcourt.

12. Shatalkin, A. I. (2012). Taksonomija. Osnovanija, principy i pravila [Taxonomy. Grounds, principles and rules]. Moscow: KMK. [In Russian].

13. Shirokov, V. A. (2017). Jazyk. Informacija. Sistema : Transdisciplinarnost v lingvistike [Tongue. Information. System: Transdisciplinarity in Linguistics]. Kyiv. [In Russian].

14. Barendregt, X. (1985). Lambda-calculus. His syntax and semantics. World, Moscow.

15. Gladun, V. P., Vashhenko, N. D., Velichko, V. Ju., Tkachenko, Ju. G. (2004). Strukturizacija i analiz dannyh $\mathrm{v}$ rastushhih piramidalnyh setjah [Structuring and analysis of data in growing pyramidal networks]. Systemni doslidzhennia ta informatsijni tekhnolohii (Systems research and information technology), 1, 8292. [In Russian].

16. Voevodsky, V. (2011). Univalent Foundations of Mathematics. In: Beklemishev L.D., de Queiroz R. (eds). Logic, Language, Information and Computation. WoLLIC 2011. Lecture Notes in Computer Science, Springer, Berlin, Heidelber, 6642.

17. Vajsfeld, M. (2004). Obektno-orientirovannoe myshlenie [Object oriented thinking]. Moscow : SPb. [In Russian].

18. David, K. E. (2012). Modeling Narrative Discourse. Ph.D. thesis, Columbia University, New York City. 